\title{
Attitudes to Death of Middle-Aged in the Context of the Covid-19 Pandemic
}

\author{
(1) Yanovskaya (Ianovska) Svitlana \\ Candidate of Psychological Sciences, Associate Professor of the Applied Psychology Department \\ V. N. Karazin Kharkiv National University, Kharkiv, 6 Svobody Sq., Kharkiv, Ukraine, 61022 \\ https:/ / orcid.org/0000-0002-5439-5269 \\ e-mail:sgyanovskaya@karazin.ua
}

Turenko Rimma

Senior Lecturer the Department of English Language, V. N. Karazin Kharkiv National University Kharkiv, 6 Svobody Sq., Kharkiv, Ukraine, 61022 e-mail: tyrenco@gmail.com

Timchenko Vyacheslav Student of the Faculty of Psychology V. N. Karazin Kharkiv National University, 4 Svobody Sq., Kharkiv, Ukraine, 61022 e-mail:slavon2805@gmail.com Psychological aspects of the attitude to death in the conditions of the COVID-19 pandemic are considered. The results of the research characterizing the attitude to death in different countries of the world during coronavirus infection are presented. The results of an empirical psychological study of the Ukrainian medieval group during the "first wave" of COVID-19 are presented. The attitude of people of the studied Ukrainian middle-aged group to the phenomenon of death in the conditions of the COVID-19 pandemic is ambivalent with a predominance of negative character. For middle-aged people, thoughts about death are not the main thing, thoughts about their own death are ambivalent, and the level of stress resistance associated with thoughts about death is average. People are afraid, in particular, not of death itself and the cessation of its existence, but of the difficult and painful process of dying. It was determined that the attitude to death is related to thoughts about their own death in the study group. An optimistic attitude towards death is associated with positive thoughts about one's own death. The problems of faith in life after death, as well as the influence of religiosity on the fear of death are considered. The presence of more positive metaphors about death, belief in life after death, the possibility of reunion with relatives, wisdom and forgiveness have led to significant differences in the results between groups of believers and atheists. The atheists studied, who are frightened by the loss of the physical world in the phenomenon of death, who imagine earthly life as the only one and believe that those who die feel fear and hopelessness before death, more often chose negative metaphors about their own death. Significant differences were identified between thoughts of death in women and men. Women, unlike men, have more pessimistic thoughts about the phenomenon of death. Women more often than men consider that thinking about death is outrageous and indicate that thoughts of death frighten and traumatize them. Thus, in the spring and summer of 2020, no significant impact of COVID-19 on the anxiety of middle-aged Ukrainians about death was identified. The situation of the second wave of coronavirus infection and the expected third (in early 2021) requires further research on the phenomenon of death in this age group.

Key words: psychology; attitude; death; COVID-19; religiousness.

Formulation of the problem. Thoughts about death at certain periods of life are the matter of concern of all age's people. With the development of media, the phenomenon of death has surrounded modern man everywhere. E.- magazines, websites, author's blogs, posts on social networks inform their viewers and readers about the death of certain people every day. In addition, modern man can face the phenomenon of death due to wars, terrorist acts, mass killings and natural disasters. It is the natural cataclysm in the form of coronavirus infection that the world faced in 2020 . Despite the fact that death itself looks like something natural, people still see something terrible in it and feel the fear of death. It is especially intensified when people can see others dying in large numbers and nothing can be done with it.

In the field of psychology, the problem of death, first of all, concerns the question of human experiences that are associated with death. These issues were addressed, in particular, by scientists of the existential direction: D. Byudzhental, L. Binswanger W. Frankl,
E. Fromm, I. Yalom and others. Existentialists agree that fear of death and anxiety about death are important characteristics of human existence. Representatives of the psychoanalytic approach Z. Freud, K.G. Jung believed that death was a natural phenomenon for anyone.

Today, the problem of death in psychology is studied by such scientists as: S.A. Abdulgalimova, Gavrilova T.A., I.Yu. Kulagina, A.Б. Kholmogorova, L.V. Senkevich, A.V. Yurevich and others. In 2020, the issue of death has expanded with studies aimed at studying attitudes towards death during a coronavirus pandemic. Based on the idea that global catastrophes increase anxiety about one's own death and fear of death, it is important to study attitudes toward death in the context of the COVID-19 pandemic, the largest and one of the most vulnerable to the abovementioned phenomena are the middle-aged.

Numerous psychological studies show that it is the people of the middle-aged group who have a crisis of middle age, which is accompanied by a number of 
intrapersonal conflicts, including existential conflict, which can give rise to thoughts about life and death. In turn, this conflict makes the problem of attitudes toward death relevant to middle-aged people, and its course during the global pandemic is important to study.

Problem analysis. The study of psychological features of the attitude to death in middle-aged people is interesting for several reasons. First, in adulthood, women and men face a crisis of middle age, as evidenced by separate studies, and as indicated by psychologists (Livehud, 1994; Solodnikov \& Solodnikova, 2009; Chernobrovkina, 2014). "The crisis of middle age has its own peculiarities ("empty nest syndrome", search for new values in life, etc.), among which there are also existential conflicts, one of which is the conflict between the desire to live and understanding the inevitability of death" Kocharyan, 2011, p. 106-107). This conflict can raise questions about life and death in middle-aged people. Second, many psychologists point out that it is in middle age that people are most acutely aware of death and fear of death.

For example, Pastushkova (2018) points out that middle-aged people often displace the topic of death in everyday life, but this does not lose its relevance. She also notes that in the middle of life, people in the postSoviet space are more afraid of death than younger or older people.

Her words are confirmed by a study conducted by scientists Kulagina and Senkevich (2013) in three cities around the world: Rome, Moscow and Yerevan. This study aimed to understand the characteristics of attitudes towards death in people of different ages, genders and places of residence. The results of the study indicate that in Yerevan and Moscow, middleaged people are more pessimistic about death than young people. At the same time, middle-aged people in Rome have a more optimistic attitude towards death, which the authors of the study associate with different economic situations in the countries.

In his article, analyzing other works on this topic, a scientist from the University of Haifa in Israel, Gary Sinoff (2017) describes the features of lethal anxiety. The scientist writes that the deadly anxiety is the greatest in middle-aged people and almost disappears in the elderly. He also notes that young people have a high level of anxiety about death, but with age the anxiety decreases. At the same time, at the age of 50, the level of anxiety about death increases again, and then decreases with age. The author noted the peculiarities of death anxiety in each age group: children 10 years old understand that death is the end of life, in adolescence there is a feeling of immortality, in middle age a person first encounters the death of relatives, parents, friends and because of this, according to the researcher, the period of maturity has the highest level of lethal anxiety. In old age, the level of anxiety about death decreases.

Yurevich's study (2018) on people's attitudes to death determined the distribution of the frequency of thoughts about death among citizens of the Russian Federation: $52 \%$ indicated that they think about death, $19 \%$ of them indicated that they think about death often. At the same time, $48 \%$ indicated that they rarely think about death.

The data of the post-Soviet space countries described above are confirmed by the data of the French sample. Studies of more than 20,000 French people have shown that thoughts of death are most relevant to people between the ages of 35 and 44 and that women are more likely to think about death than men. The researchers also summarized data from their own study, which calculated the percentage of people who fear death in different age groups. Thus, of young people aged 18 to 24 , only $40 \%$ have a fear of death. In people aged 25 to 34 , fear of death was recorded in $43 \%$ of cases. In middle-aged people (35 to 44 years) fear of death was recorded in $65 \%$ of cases, and in people aged 55 to 69 years, fear of death was recorded in $62 \%$ of cases. The above data confirm the opinion that it is in the middle age that the fear of death is exacerbated (Reinhold, 2004, pp. 342 - 343).

In December 2019, the first case of a new type of coronavirus, called COVID-19, was recorded in the Chinese city of Wuhan. As early as May 2020, the virus killed more than 300,000 people worldwide (World Health Organization, 2020). The increase in the number of patients has led to a large-scale pandemic that has spread to all countries of the world. A large number of people remained self-isolated, and in almost all countries people began to buy basic necessities en masse, and sometimes to show physical and verbal aggression in supermarkets (R.E. Menzies, R.G. Menzies, 2020; Devakumar, Shannon, Bhopal, \& Abubakar, 2020).

We can say that the global panic has affected the lives of people in some way, and these assumptions are confirmed by a study of a Chinese group scientists who in a sample of five thousand were able to show that increasing the severity of coronavirus infection is associated with adverse mental health consequences. problems due to the phenomenon of loneliness, job loss, death of loved ones and the growth rate of COVID-19 (Li, Yang, Dou, \& Cheung, 2020).

Such anxious reactions of people to the problem of coronavirus infection lead to the idea of the impact of this anxiety on the increase or decrease in fear of death. Thus, the WHO in the Clinical Case Management COVID-19 (2020) indicates the possible presence of fear of death and death in patients with coronavirus infection. And the observations of the American expert Jong-Fast (2020) indicate that during a pandemic of coronavirus infection, people often use protective 
mechanisms in the form of attempts to prevent death (for example, buy a lot of drugs for colds) or a denial mechanism.

A study by a group of scientists from Hong Kong, Ahorsu, Chung-Ying, Imani, Saffari, Griffiths, \& Pakpour, (2020) showed that in a psychometric assessment of COVID-19 fear, the item "I am afraid of losing my life due to coronavirus infection" had the greatest factor significance, which allowed scientists to suggest a high impact of fear of coronavirus infection on the fear of their own death.

A study by Australian scientists Newton-John, Chambers, Menzies, R.E., \& Menzies, R.G. (2020), in which 810 Australians took part, was aimed at identifying links between fear of death during a pandemic. The study found a positive correlation between fear of death and anxious judgments associated with COVID-19.

The American clinical psychologist Firestone (2020) believes that increasing or decreasing the fear of one's own death can be influenced by a number of factors: financial failures, failures, accidents, etc. At the same time, the scientist points out that the greatest influence on the growth of anxiety about his own death is caused by man-made and natural disasters, including the pandemic of coronavirus infection.

It is worth noting that a study by scientists from Saudi Arabia Alkhamees, Alrashed \& Alzunaydi (2020) showed a slight effect of coronavirus infection on anxiety and fear in humans. A study of the same factors in the Philippines, by contrast, showed an increase in anxiety, fear, and depression (Tee M.L., Tee C.A., \& Anlacan, 2020). And the first in Europe study of the effects of the coronavirus pandemic on fears and anxiety, conducted in Austria, showed that the psychological state of $37.7 \%$ of COVID-19 subjects was negatively affected: one in ten subjects had increased anxiety (Traunmüller, Stefitz, \& Gaisbachgrabner, 2020).
Thus, it can be said that a number of studies have shown the negative effects of coronavirus infection on the level of anxiety and fear about death. Some studies have found a link between fear of death and a coronavirus pandemic. However, some studies have not found a significant effect of COVID-19 on death anxiety.

As there are no unambiguous results of the impact of COVID-19 on the level of anxiety and fear about death at this time, we decided to conduct our own study on the Ukrainian sample.

The aim of the study: to determine the attitude of middle-aged people to the phenomenon of death during the COVID-19 pandemic.

Research methods: questionnaires (method "Attitude to death" developed by I.Yu. Kulagina and L.V. Senkevich, method "Scale of Attitude to Death" developed by Dale W. Hardt and method "Metaphors of Personal Death", developed by J. McLennan) and methods of mathematical and statistical data processing. The following statistical programs were used in processing the obtained empirical data of the study: Microsoft Excel 2016 and statistical package for social sciences IBM SPSS Statistics 20.0 (MannWhitney test; Spearman correlation coefficient).

Sample description. The study involved 76 subjects. Of these, 55 were women $(72.3 \%$ of the total sample) and 21 were men (27.7\% of the total sample). The age of the subjects varies from 35 to 55 years old. The average age of the sample is 44 years old. The subjects were divided into two groups according to religious beliefs: 22 atheists and 54 believers. The study was conducted in the spring and summer of 2020, that corresponded the first wave of COVID-19.

Research results. Analysis of data by the method of "Attitude to Death" I.Yu. Kulagina and L.V. Senkevich. As shown in Table 1, to the first and second questions, among all the answer options, most of the respondents chose the answer options that belong to the scale of optimism about death.

Table 1. Indicators According to the Method of "Attitude to Death" I.Yu. Kulagina and L.V. Senkevich

\begin{tabular}{|l|l|l|l|l|}
\hline No & \multicolumn{1}{|c|}{ Questions } & \multicolumn{3}{|c|}{ Answer options and distribution in\% } \\
\hline 1 & $\begin{array}{l}\text { What do you } \\
\text { think life is } \\
\text { like? }\end{array}$ & Joyful and exciting (82,4\%) & Insignificant and meaningless (0\%) & $\begin{array}{l}\text { Continuity of troubles, } \\
\text { sufferings } \\
\text { and losses } \\
\text { and.6\%) }\end{array}$ \\
\hline 2 & $\begin{array}{l}\text { How do you } \\
\text { feel about the } \\
\text { difficulties you } \\
\text { encounter in } \\
\text { your life? }\end{array}$ & $\begin{array}{l}\text { Life is hard and there is nothing } \\
\text { you can do about it }(13.2 \%)\end{array}$ & $\begin{array}{l}\text { I try to overpower them, because } \\
\text { otherwise I will not succeed (51.3\%) }\end{array}$ & $\begin{array}{l}\text { Difficulties harden my } \\
\text { character and make me } \\
\text { stronger }(35.5 \%)\end{array}$ \\
\hline 3 & $\begin{array}{l}\text { How do you } \\
\text { imagine life } \\
\text { after life? }\end{array}$ & $\begin{array}{l}\text { Our earthly life is one and } \\
\text { nothing will happen after it } \\
(53.9 \%)\end{array}$ & $\begin{array}{l}\text { In the next life I will not repeat my } \\
\text { mistakes and I will be happier } \\
(26.3 \%)\end{array}$ & $\begin{array}{l}\text { I don't know what the } \\
\text { next life will be like and } \\
\text { it scares me }(19.8 \%)\end{array}$ \\
\hline 4 & $\begin{array}{l}\text { When you } \\
\text { think about } \\
\text { death, what }\end{array}$ & $\begin{array}{l}\text { Physical suffering before death } \\
(36.8 \%)\end{array}$ & $\begin{array}{l}\text { Loss of this world (61.8\%) } \\
\text { afreducibility of the } \\
\text { afterlife }(1.4 \%)\end{array}$ \\
\hline
\end{tabular}




\begin{tabular}{|c|c|c|c|c|c|c|c|c|c|c|}
\hline № & \multirow{2}{*}{$\begin{array}{l}\text { Questions } \\
\text { scares you the } \\
\text { most? }\end{array}$} & \multicolumn{9}{|c|}{ Answer options and distribution in $\%$} \\
\hline & & & & & & & & & & \\
\hline 5 & $\begin{array}{l}\text { If you have } \\
\text { made many } \\
\text { mistakes in this } \\
\text { life, do you } \\
\text { think you will } \\
\text { have to pay for } \\
\text { them after } \\
\text { death? }\end{array}$ & \multicolumn{2}{|c|}{$\begin{array}{l}\text { No, I pay for my mistakes in this } \\
\text { life }(55.3 \%)\end{array}$} & \multicolumn{4}{|c|}{ Yes, but now I don't care $(9.2 \%)$} & \multicolumn{3}{|c|}{$\begin{array}{l}\text { Yes, and it worries me a } \\
\text { lot }(35.5 \%)\end{array}$} \\
\hline 6 & $\begin{array}{l}\text { Do you think } \\
\text { that your } \\
\text { children and } \\
\text { grandchildren } \\
\text { will pay for } \\
\text { your mistakes? }\end{array}$ & \multicolumn{2}{|c|}{ No, it's superstition $(36.9 \%)$} & \multicolumn{4}{|c|}{ Yes, it is possible $(53.9 \%)$} & \multicolumn{3}{|c|}{$\begin{array}{l}\text { Yes, and it confuses me } \\
(9.2 \%)\end{array}$} \\
\hline 7 & $\begin{array}{l}\text { What do you } \\
\text { think death can } \\
\text { give you? }\end{array}$ & $\begin{array}{l}\text { Separation } \\
\text { from people } \\
\text { close to me } \\
(41.8 \%)\end{array}$ & $\begin{array}{l}\text { Deprivation of } \\
\text { the burden of } \\
\text { life }(6.7 \%)\end{array}$ & $\begin{array}{l}\text { Reunion with } \\
\text { relatives and } \\
\text { friends }(20.1 \%)\end{array}$ & $\begin{array}{l}\text { Punisl } \\
\text { my } m \\
\text { sins }(3\end{array}$ & $\begin{array}{l}\text { ment } \\
\text { istakes } \\
1 \%)\end{array}$ & $\begin{array}{l}\text { for } \\
\text { and }\end{array}$ & $\begin{array}{l}\text { Loss } \\
\text { joys } \\
\text { lif } \\
(18.6\end{array}$ & & $\begin{array}{l}\text { Forgiveness } \\
\text { of sins } \\
(9.7 \%)\end{array}$ \\
\hline 8 & $\begin{array}{l}\text { How do you } \\
\text { think people } \\
\text { behave, } \\
\text { knowing that } \\
\text { they will die } \\
\text { soon? }\end{array}$ & $\begin{array}{l}\text { Feel fear and } \\
\text { hopelessness } \\
(35.9 \%)\end{array}$ & $\begin{array}{l}\text { Accept the } \\
\text { inevitability of } \\
\text { the end } \\
(32.7 \%)\end{array}$ & $\begin{array}{l}\text { Trying to dela } \\
\text { end, "traded" }(9 .\end{array}$ & $\begin{array}{l}y \text { the } \\
6 \%)\end{array}$ & $\begin{array}{l}\text { Do } \\
\text { with } t\end{array}$ & $\begin{array}{l}\text { not } \\
\text { nis }(15\end{array}$ & $\begin{array}{l}\text { agree } \\
.9 \%)\end{array}$ & $\begin{array}{l}\text { Fee } \\
\text { rese } \\
\text { env } \\
(5.9\end{array}$ & $\begin{array}{l}1 \text { anger, } \\
\text { entment and } \\
y \text { of others } \\
\%)\end{array}$ \\
\hline 9 & $\begin{array}{l}\text { What qualities } \\
\text { appear in } \\
\text { people who say } \\
\text { goodbye to } \\
\text { life? }\end{array}$ & $\begin{array}{l}\text { Wisdom and } \\
\text { forgiveness } \\
(47.4 \%)\end{array}$ & $\begin{array}{l}\text { Sorrow, fear } \\
\text { and despair } \\
(39.5 \%)\end{array}$ & $\begin{array}{l}\text { Courage and res } \\
(9.2 \%)\end{array}$ & lience & $\begin{array}{l}\text { Expec } \\
\text { parad }\end{array}$ & $\begin{array}{l}\text { tation } \\
\text { se life }\end{array}$ & $\begin{array}{l}s \text { of } \\
(0 \%)\end{array}$ & $\begin{array}{l}\text { Agg } \\
\text { env } \\
(3.9\end{array}$ & $\begin{array}{l}\text { gression and } \\
y \text { of others } \\
\%)\end{array}$ \\
\hline 10 & $\begin{array}{l}\text { What feelings } \\
\text { does the dying } \\
\text { person evoke } \\
\text { in relatives and } \\
\text { friends? }\end{array}$ & $\begin{array}{l}\text { Anxiety and a } \\
(72.4 \%)\end{array}$ & sense of debt & $\begin{array}{l}\text { uffering and sa } \\
18.4 \%)\end{array}$ & rificial & love & Fear & and re & ectio & $\mathrm{n}(9.2 \%)$ \\
\hline
\end{tabular}

According to the authors of the method Kulagin and Senkevich (2013), the first two questions of the questionnaire are related to satisfaction with one's own life, because this factor, in their opinion, correlates with an optimistic and pessimistic attitude to death. Based on the results of the answers, we can say that most of the respondents in this sample are satisfied with their own lives, considering it joyful and exciting.

The third, fourth, sixth and seventh questions were answered by most of the respondents, which refers to the scale of pessimistic attitude to death. Researchers believe that earthly life is one, after it there will be nothing and it scares them, because the worst thing for them is the loss of this world, physical suffering before death and separation from loved ones.

To the fifth, eighth, ninth and tenth questions, the respondents chose answer options that relate to an optimistic attitude to death. They believe that death will not bring additional suffering associated with correcting past mistakes, the end of life is inevitable (people are born and die), so a person before death often becomes wiser and more resilient and feels the support and care of loved ones. In addition to the analysis described above for individual questions, the interpretation of all the answers of the subjects according to the criteria established by the authors of the methodology was performed. After calculating the average score of this sample, it was determined that it is equal to 1.1, which falls between 0 and 3 points with a positive mark. This result indicates that according to this method, this sample showed an ambivalent attitude to the phenomenon of death. It was determined that the subjects more often chose the answer options that belong to the scale of ambivalent attitude to death. It can be added that the subjects equally chose the answer options that belong to the scale of pessimistic attitude to death and to the scale of optimistic attitude to death.

Data from Dale W. Hardton's "Scale of Attitudes to Death" determine the following characteristics in the 
subjects: the level of stress resistance associated with thoughts about death, the general attitude to the phenomenon of death (individual and general sampling) and the rate of thoughts about death.

The respondents of this sample most often chose the answers: "Thinking about death is not the main thing for me" and "I'm not afraid of thoughts about death, but they bother me." At the same time, none of the respondents chose the following answers: "It's really easy to think about death", "Thoughts about death are very pleasant", "When I think about death - I have a great mood" and "Thinking about death is a great idea".

The subjects did not choose the extreme options with an optimistic value of the attitude to death, which may mean the absence in this sample of subjects who have a high level of optimism about the death. It can be added that the answers with a negative value of the attitude to death, the subjects chose more often. Thus, the extreme answer "Thinking about death is just shameful" was chosen by $7 \%$, the option "I hate the word" death "'" was chosen by $27 \%$ and the option "Thoughts about death just hurt me" was chosen by $18 \%$. Therefore, the subjects more often chose extreme variants with negative statements than extreme variants with positive statements about the phenomenon of death.

In addition to the above-described analysis of the percentage distribution of choice of answer options, were is the interpretation of all answers studied by the criteria that were established in the method of Dale W. Hardton. The average score of this sample is 225, which falls under the following characteristic of the attitude to death: "Thinking about death is not the main thing for me." The analysis of integrated indicators of the method determined the average level of stress resistance, which is associated with thoughts of death, in the subjects of this sample.

Thus, the sample is characterized by a moderately negative attitude to the phenomenon of death, thoughts about death are not the main ones and there is an average level of stress resistance to thoughts about death. These data correspond to those of pilot investigation, carried out in autumn 2019.

Data on the method of "Metaphors of Personal Death" by J. McLennan were divided into two subscales (according to the interpretive requirements of the method): a subscale of negative metaphors and a subscale of positive metaphors.

Figure 1 clearly shows the advantage of the positive metaphors of the subjects of this sample to describe their thoughts about their own death. But there are also negative metaphors. Thus, the thoughts about their own death in the subjects of this sample are ambivalent with a slight deviation towards the positive ones.

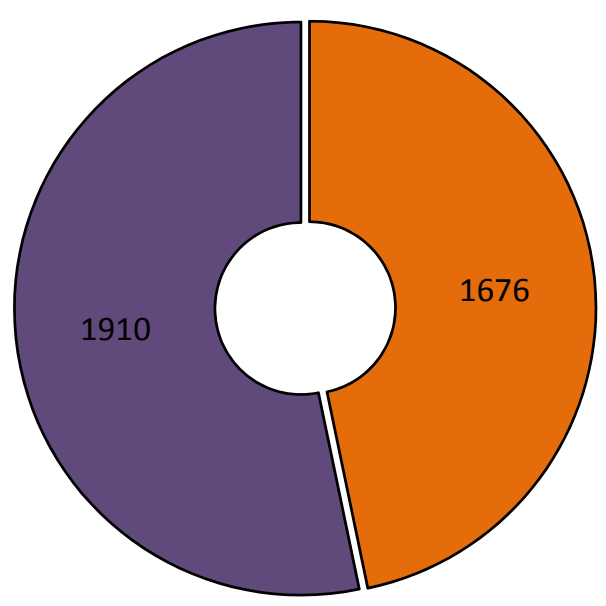

$\square$ A subscale of negative metaphors $\square$ A subscale of positive metaphors

Figure 1. Comparative Diagram of the Sum of Points on the Negative and Positive Subscales of the Method "Metaphors of Personal Death" by J. McLennan

According to the results of correlation analysis, the relationship between the studied indicators of attitudes to death of middle-aged people was determined. The general attitude to death is directly related to the scale of attitude to one's own death and inverse to the subscale of negative metaphors of personal death. Thus, the more optimistic the general attitude towards death is, the fewer there are negative metaphors about one's own death. The subjects who are frightened by the loss of the physical world in the phenomenon of death, who represent earthly life as the only ones who believe that those who die feel fear and hopelessness before death, more often choose negative metaphors about their own death. 
Table 2. Indicators of Correlation Analysis of Results by Methods of Treatment of Death

\begin{tabular}{|c|c|c|c|c|}
\hline & $\begin{array}{l}\text { "Attitude to } \\
\text { Death" }\end{array}$ & $\begin{array}{l}\text { "Scale of Attitude } \\
\text { to One's own } \\
\text { death" }\end{array}$ & $\begin{array}{l}\text { "Metaphors of } \\
\text { Personal Death" } \\
\text { (Positive) }\end{array}$ & $\begin{array}{l}\text { "Metaphors of } \\
\text { Personal Death" } \\
\text { (Negative) }\end{array}$ \\
\hline \multirow[t]{3}{*}{ "Attitude to Death" } & 1,000 &, $388^{* *}$ & ,121 &,$- 345^{* *}$ \\
\hline & &, 001 & ,296 &, 002 \\
\hline & 76 & 76 & 76 & 76 \\
\hline \multirow{3}{*}{$\begin{array}{l}\text { "Scale of Attitude to } \\
\text { One's own death" }\end{array}$} &, $388^{* *}$ & 1,000 &, $379^{* *}$ &,$- 473^{* *}$ \\
\hline &, 001 & &, 001 &, 000 \\
\hline & 76 & 76 & 76 & 76 \\
\hline \multirow{3}{*}{$\begin{array}{lr}\text { "Metaphors } & \text { of } \\
\text { Personal } & \text { Death" } \\
\text { (Positive) } & \end{array}$} & ,121 &, $379^{* *}$ & 1,000 &,$- 354^{* *}$ \\
\hline & ,296 & ,001 & &, 002 \\
\hline & 76 & 76 & 76 & 76 \\
\hline \multirow{3}{*}{$\begin{array}{lr}\text { "Metaphors } & \text { of } \\
\text { Personal } & \text { Death" } \\
\text { (Negative) } & \end{array}$} &,$- 345^{* *}$ &,$- 473^{* *}$ &,$- 354^{* *}$ & 1,000 \\
\hline & ,002 &, 000 &, 002 & \\
\hline & 76 & 76 & 76 & 76 \\
\hline
\end{tabular}

The scale of attitude to one's own death has a direct connection with the sub-scale of positive metaphors of personal death and the inverse with the sub-scale of negative metaphors of personal death. The existence of this connection is related to one of the main functions of metaphor. According to J. Lakoff and M. Johnson (2008), metaphor provides the activation of mental activity of the individual, with its help it is possible to model some life situations and relationships. Metaphors structure the image of reality in which the attitude to one's own death is formed. This unique semantic space provides the "inseparability" of metaphors of different signs and determines the place of attitude to one's own death, provides a way of presenting psychological difficulties and means of solving them.

According to the results of the comparative analysis, a significant discrepancy $(\mathrm{p}=0.040)$ was recorded between women and men in terms of reflections on their own death (see Table 3). Women, compared to men, have pessimistic thoughts about death. It's true, women are more likely than men to think that thinking about death is outrageous and point out that thoughts of death frighten them. In addition, for women, thoughts of death are traumatic. Similar results were presented in Reinhold's work (2004, pp. 342-343) and in Fifel's study (1959).

Table 3. Indicators of Comparative Analysis of Results by Methods of Treatment of Death

\begin{tabular}{|c|c|c|c|}
\hline \multirow{2}{*}{ Indicator } & Groups & Middle rank & \multirow{2}{*}{ Significance level } \\
\hline \multirow{2}{*}{$\begin{array}{c}\text { "Scale of Attitude to one's } \\
\text { own Death" }\end{array}$} & Women 55 & 0,40 \\
\cline { 2 - 3 } & Men 21 & 35,33 & \\
\cline { 2 - 3 } & Total 76 & 46,81 & \multirow{2}{*}{0,0001} \\
\cline { 2 - 3 } $\begin{array}{c}\text { "Metaphors of Personal } \\
\text { Death" (Positive) }\end{array}$ & Believers 54 & 47,16 & 17,27 \\
\cline { 2 - 3 } & Atheists 22 & & \\
\hline
\end{tabular}

Significant differences between atheists and believers were also identified. The semantic space of beliefs about the own death of believers is filled with more positive metaphors than atheists.

Conclusions. The attitude of the people of the studied Ukrainian middle-aged group to the phenomenon of death in the course of the COVID-19 pandemic is ambivalent with a predominance of negative character. For middle-aged people, thoughts about death are not the main thing, thoughts about their own death are ambivalent, and the level of stress resistance associated with thoughts about death is average.

It was determined that the attitude to death is associated with thoughts about their own death in the study group (optimistic attitude towards death is associated with positive thoughts about their own death).

Significant differences were identified between thoughts about death in women and men (women, unlike men, have more pessimistic thoughts about the phenomenon of death) and believers and atheists (believers' metaphors that indicate attitudes toward death are more positive).

Thus, in the spring and summer of 2020, no significant impact of COVID-19 on the anxiety of middle-aged Ukrainians about death was identified. The situation of the second wave of coronavirus infection and the expected third (in early 2021) requires further research on the phenomenon of death in this age group. 


\section{Список посимань}

АбАулгалимова, С.А. (2012). Отношение к собственной смерти и переживание страха смерти. Вестник Сочиально-педагогического института, 1(4). https://cyberleninka.ru/article/n/otnoshenie-ksobstvennoy-smerti-i-perezhivanie-strahasmerti/viewer

Гаврияова, Т.А. (2001). Экзистенциацьный страх смерти и танатическая тревога: методы исследования и Аиагностики. Прикладная психология, 6, 1-8.

Кочарян, А.С. \& Аисеная, А.М. (2011). Психология переживаний. Харків: виА-во ХНУ імені В.Н. Каразіна, 224.

Кравченко, А.В. (2017). К вопросу об изучении форм проявАения страха смерти. Гуманизачия образования, 5 . https://cyberleninka.ru/article/n/k-voprosu-obizuchenii-form-proyavleniya-straha-smerti

Кулагина, И.Ю. \& Сенкевич, А.В. (2013). Отношение к смерти: возрастные, региональные и гендерные разАичия. Культурно-историческая психология, 9(4), 5864. http://psyjournals.ru/kip/2013/n4/66037.shtml.

Аакофф, А. \& Ажонсон, М. (2008). Метафоры, которыми мы живем. М.: АКИ, 256.

Аивехуд, Б. (1994). Кризисы жизни - шансы жизни: Развитие человека между детством и старостью. Калуга: Ауховное познание, 217.

Пастушкова, А.С. (2018). Отношение к смерти на разных возрастных етапах. Academy, 4(31). https://cyberleninka.ru/article/v/otnoshenie-ksmerti-na-raznyh-vozrastnyh-etapah.

Психологическая диагностика: методика "Шкала отношения к смерти (Dale V. Hardt)". https:/ / sites.google.com/site/test $300 \mathrm{~m} /$ skos.

РейнгольА, Аж. (2004). Мать, тревога и смерть. Комплекс трагической смерти. М: ПЕР СЭ.

Солодников, В.В. \& Солодникова, И.В. (2009). Кризис среднего возраста: теоретическая интерпретация переживаемого опыта. Мониторинг общественного мнения, 4 (92).

Франкл, В. (1990). Человек в поисках смысла. Москва: Прогресс, 368.

Холмогорова, А.Б. (2003). Страх смерти: культурные источники и способы психологической работы. Московский психотерапевтический журнал, 2, 120-132. http://psyjournals.ru/mpj/2003/n2/Holmogorova.sh tml

Чернобровкина, С.В. (2014). Гендерные особенности переживания и преодоления кризиса средины жизни. Вестник Омского университета. Серия «Психология», 2, 30-42. https://cyberleninka.ru/ article/n/gendernye-osobennosti-perezhivaniya-ipreodoleniya-krizisa-serediny-zhizni/viewer

Юревич, А.В. (2018). Психологические аспекты отношения к смерти. Ярославский педагогический вестник, 1, 123-132. http://vestnik.yspu.org/releases/ 2018_1/21.pdf

Я九ом, И. (2008). Вгладвгваясь в солнще. Жизнь без страха смерти. Москва: Эксмо, 384.

Ahorsu, D. K., Chung-Ying, L., Imani, V., Saffari, M., Griffiths, M. D., \& Pakpour, A. H. (2020). The Fear of COVID-19 Scale: Development and Initial Validation. International Journal of Mental Health and Addiction. https://doi.org/10.1007/s11469-020-00270-8

Alkhamees, A.A., Alrashed, S.A. \& Alzunaydi, A.A. (2020). The Psychological Impact of COVID-19 Pandemic on the General Population of Saudi Arabia. Comprehensive
Psychiatry, 102, 152-192. https://doi.org/10.1016/ j.comppsych.2020.152192

Devakumar, D., Shannon, G., Bhopal, S. S., \& Abubakar, I. (2020). Racism and Discrimination in COVID-19 Responses. Health Psychology; 39(5), 355-357. https://doi.org/10.1016/S0140-6736(20)30792-3)

Feifel, Herman (1959). Attitudes Toward Death in Some Normal and Mentally Populations. In Feifel, Herman (Ed.), The Meaning of Death. New York: McGraw-Hill.

Firestone, R. W. (2020). Death Anxiety and the Coronavirus. Psychology Today. https://www.psychologytoday.com/ us/blog/the-human-experience/202005/deathanxiety-and-the-coronavirus

Jong-Fast, M. (2020). Why are so many baby boomers in denial over the Coronavirus? Vogue. https://www.vogue.com/article/coronavirus-babyboomers-at-risk

Li, J.B., Yang, A., Dou, K., \& Cheung, R.Y.M. (2020). SelfControl Moderates the Association between Perceived Severity of the Coronavirus Disease 2019 (COVID-19) and Mental Health Problems among the Chinese Public. PsyArXiv Preprints. https://doi.org/10.31234/osf.io/2xadq

Menzies, R.E. \& Menzies, R.G. (2020). Death Anxiety in the Time of COVID-19: Theoretical Explanations and Clinical Implications. The Cognitive Behavior Therapist, 13, 1-11. https://doi.org/10.1017/S1754470X20000215

Newton-John, T., Chambers, S., Menzies, R.E., \& Menzies, R.G. (2020). Psychological Distress and COVID-19: Estimations of Threat and the Relationship with Death Anxiety. Cognitive behavior Therapist, 13. https://doi.org/10.1017/S1754470X20000215

Sinoff, G. (2017). Thanatophobia (Death Anxiety) in the Elderly: The Problem of the Child's Inability to Assess Their Own Parent's Death Anxiety State. Faculty of Social Welfare and Health Sciences, Department of Gerontology, University of Haifa, Haifa, Israel. https://www.frontiersin.org/articles/10.3389/fmed.2 017.00011/full\#B26.

Tee, M.L, Tee, C.A. \& Anlacan, J.P. (2020). Psychological Impact of COVID-19 Pandemic in the Philippines. Journal of Affective Disorders, 277, 379-391. https://doi.org/10.1016/j.jad.2020.08.043

Traunmüller, C., Stefitz, R., Gaisbachgrabner, K. \& al. (2020). Psychological Correlates of COVID-19 Pandemic in the Austrian Population. BMC Public Health, 20, 1395. https://doi.org/10.1186/s12889-020-09489-5

World Health Organization (2020). Coronavirus disease (COVID-19): Situation report - 117. https://www.who.int/docs/defaultsource/coronaviruse/situation-reports/20200516covid-19-sitrep 117.pdf?sfvrsn=8f562cc_2 [Ref list]

\section{References}

Abdulgalimova, S.A. (2012). Attitude Towards one's own Death and the Experience of Fear of Death. Vestnik Sotsialno-pedagogicheskogo instituta, 1(4). https://cyberleninka.ru/article/n/otnoshenie-ksobstvennoy-smerti-i-perezhivanie-strahasmerti/viewer [in Russian].

Gavrilova, T.A. (2001). Existential Fear of Death and Thanatic Anxiety: Research and Diagnostic Methods. Prikladnaya psibologiya, 6, 1-8. [in Russian].

Kocharyan, A.S. \& Lisenaya, A.M. (2011). Psychology of Emotions. Harkiv: vid-vo HNU imeni V.N. Karazina, 224. [in Russian]. 
Kravchenko, L.V. (2017). On the Study of Manifestation of Death Fear Forms. Gumanizatsiya obrazovaniya, 5. https://cyberleninka.ru/article/n/k-voprosu-obizuchenii-form-proyavleniya-straha-smerti [in Russian].

Kulagina, I.Yu. \& Senkevich, L.V. (2013). Attitude towards death: age, regional and gender differences. Kulturnoistoricheskaya psibologiza, 9(4), 58-64. http://psyjournals.ru/kip/2013/n4/66037.shtml. [in Russian].

Lakoff, D. \& Dzhonson, M. (2008). The Metaphors We Live by. M.: LKI, 256. [in Russian].

Livehud, B. (1994). Crises of Life - Chances of Life: Human Development between Childhood and Old Age. Kaluga: Duhovnoe poznanie, 217. [in Russian].

Pastushkova, A.S. (2018). Attitude towards Death at Different Age Stages. Academy, 4(31). https://cyberleninka.ru/article/v/otnoshenie-ksmerti-na-raznyh-vozrastnyh-etapah. [in Russian].

Psychological diagnostics: methodology "Scale of Attitude to Death (Dale V. Hardt)". https:/ / sites.google.com/site/ test $300 \mathrm{~m} /$ skos. [in Russian].

Reyngold, D. (2004). Mother, Anxiety and Death. Tragic Death Complex. M: PER SE. [in Russian].

Solodnikov, V.V. \& Solodnikova, I.V. (2009). Middle-aged Crisis: A Theoretical Interpretation of Experiences. Monitoring obschestvennogo mneniya, 4 (92). [in Russian].

Frankl, V. (1990). A man in Search of Meaning. Moskva: Progress, 368. [in Russian].

Holmogorova, A.B. (2003). Fear of Death: Cultural Sources and Ways of Psychological Work. Moskovskiy psiboterapevticheskiy zhurnal, 2, 120-132. http://psyjournals.ru/mpj/2003/n2/Holmogorova.sh tml [in Russian].

Chernobrovkina, S.V. (2014). Gender Characteristics of Experiencing and Overcoming the Middle-aged Crisis. Vestnik Omskogo universiteta. Seriya «Psihologiya», 2, 30-42. https://cyberleninka.ru/article/n/gendernyeosobennosti-perezhivaniya-i-preodoleniya-krizisaserediny-zhizni/viewer [in Russian].

Yurevich, A.V. (2018). Psychological Aspects of the Attitude towards Death. Yaroslavskiy pedagogicheskiy vestnik, 1, 123132. http://vestnik.yspu.org/releases/2018_1/21.pdf [in Russian].

Yalom, I. (2008). Peering into the Sun. Life without Fear of Death. Moskva: Eksmo, 384. [in Russian].

Ahorsu, D. K., Chung-Ying, L., Imani, V., Saffari, M., Griffiths, M. D., \& Pakpour, A. H. (2020). The Fear of COVID-19 Scale: Development and Initial Validation. International Journal of Mental Health and Addiction. https://doi.org/10.1007/s11469-020-00270-8

Alkhamees, A.A., Alrashed, S.A. \& Alzunaydi, A.A. (2020). The Psychological Impact of COVID-19 Pandemic on the General Population of Saudi Arabia. Comprehensive
Psychiatry,

102,

$152-192$

https://doi.org/10.1016/j.comppsych.2020.152192

Devakumar, D., Shannon, G., Bhopal, S. S., \& Abubakar, I. (2020). Racism and Discrimination in COVID-19 Responses. Health Psychology; 39(5), 355-357. https://doi.org/10.1016/S0140-6736(20)30792-3)

Feifel, Herman (1959). Attitudes Toward Death in Some Normal and Mentally Populations. In Feifel, Herman (Ed.), The Meaning of Death. New York: McGraw-Hill.

Firestone, R. W. (2020). Death Anxiety and the Coronavirus. Psychology Today. https://www.psychologytoday.com/ us/blog/the-human-experience/202005/deathanxiety-and-the-coronavirus

Jong-Fast, M. (2020). Why are so many baby boomers in denial over the Coronavirus? Vogue. https://www.vogue.com/article/coronavirus-babyboomers-at-risk

Li, J.B., Yang, A., Dou, K., \& Cheung, R.Y.M. (2020). SelfControl Moderates the Association between Perceived Severity of the Coronavirus Disease 2019 (COVID-19) and Mental Health Problems among the Chinese Public. PsyArXiv Preprints. https://doi.org/10.31234/osf.io/2xadq

Menzies, R.E. \& Menzies, R.G. (2020). Death Anxiety in the Time of COVID-19: Theoretical Explanations and Clinical Implications. The Cognitive Behavior Therapist, 13, 1-11. https://doi.org/10.1017/S1754470X20000215

Newton-John, T., Chambers, S., Menzies, R.E., \& Menzies, R.G. (2020). Psychological Distress and COVID-19: Estimations of Threat and the Relationship with Death Anxiety. Cognitive behavior Therapist, 13. https://doi.org/10.1017/S1754470X20000215

Sinoff, G. (2017). Thanatophobia (Death Anxiety) in the Elderly: The Problem of the Child's Inability to Assess Their Own Parent's Death Anxiety State. Faculty of Social Welfare and Health Sciences, Department of Gerontology, University of Haifa, Haifa, Israel. https://www.frontiersin.org/articles/10.3389/fmed.2 017.00011/ full\#B26.

Tee, M.L, Tee, C.A. \& Anlacan, J.P. (2020). Psychological Impact of COVID-19 Pandemic in the Philippines. Journal of Affective Disorders, 277, 379-391. https://doi.org/10.1016/j.jad.2020.08.043

Traunmüller, C., Stefitz, R., Gaisbachgrabner, K. \& al. (2020). Psychological Correlates of COVID-19 Pandemic in the Austrian Population. BMC Public Health, 20, 1395. https://doi.org/10.1186/s12889-02009489-5

World Health Organization (2020). Coronavirus disease (COVID-19): Situation report - 117. https://www.who.int/docs/defaultsource/coronaviruse/situation-reports/20200516covid-19-sitrep 117.pdf?sfvrsn=8f562cc_2 [Ref list]

Яновська Світлана Германівна кандидат психологічних наук, дочент кафедри прикладної психологї̈, Харківський начіональний університет імені В. Н. Каразіна майдан Свободи, 6, Харків, Украӥна, 61022

Туренко Римма Меонардівна стариий викладач кафедри англійської мови, Харківський начіональний університет імені В. Н. Каразіна майдан Свободи, 6, Харків, Украйна, 61022

Тімченко В'ячеслав Вомодимирович студент факультету психології, Харківський начіональний університет імені В.Н. Каразіна майдан Свободи 4, Харків, Украйна, 61022

Розглянуто психологічні аспекти ставлення до смерті в умовах пандемії COVID-19. Представлено результати досліджень, що характеризують ставлення до смерті в різних краӥнах світу під час коронавірусної інфекиї. Подано результати емпіричного психологічного дослідження украйнської середньовікової групи під час «першої хвилі» COVID-19. Ставлення людей досліджуваної 
украйнськой середньовікової групи до феномену смерті в умовах пандемї СОVID-19 має амбівалентний з превалюванням негативного характеру. Аля пюдей середнього віку думки про смерть не є головними, думки про власну смерть - амбівалентні, а рівень стресостійкості, який пов'язаний з думками про смерть, є середнім. Аюди бояться, зокрема, не самої смерті та припинення свого існування, а важкого і болісного прочесу вмирання. Визначено, що ставлення до смерті пов'язано з думками про власну смерть у досліджуваної групи. Оптимістичне ставлення до смерті пов'язано з позитивними думками про власну смерть. Розглянуто проблеми віри в життя після смерті, а також впливу релігійності на страх смерті. Наявність більшої кількості позитивних метафор про смерть, віра в життя після смерті, можливість возз'єднання з рідними, мудрість та прощення стало підгрунтям значущих розбінностей результатів між групами віруючих та атеїстів. Аосліджувані атеїсти, яких у феномені смерті лякає втрата фізичного світу, які уявляють земне життя сдиним та вважатоть, що ті, хто помирають, відиувають страх $і$ безнадію перед смертю, частіше обирали негативні метафори про власну смерть. Були визначені значущі розбіжності між роздумами про смерть у жінок $і$ чоловіків. Жінки, на відміну від чоловіків, мають більш песимістичні роздуми про феномен смерті. Жінки частіше за чоловіків вважаюоть, що думати про смерть обурливо та вказують, що думки про смерть їх лакають та травмують.

Кнючові слова: психологія; ставлення; смерть; COVID-19; релігійність.

Яновская Светмана Германовна кандидат психологических наук, дочент кафедры прикладной психологии, Харьковский начиональныгй университет имени В.Н. Каразина, пл. Свободъг, 6, Харьков, Украина, 61022

Туренко Римма Меонардовна стариий преподаватель кафедры английского язьгка, Харьковский начиональный университет имени В.Н. Каразина пл. Свободы, 6, Харьков, Украина, 61022

Тимченко Вячеслав Вмадимирович студент факультета психологии, Харьковский начиональный университет имени В.Н. Каразина пломадь Свободы 4, Харьков, Украина, 61022

Рассмотрены психологические аспекты отношения к смерти в условиях пандемии СОVЛD-19. Представлены результаты исследований, характеризующие отношение к смерти в различных странах мира во время коронавирусной инфекиии. Представлены результаты эмпирического психологического исследования украинской средневозрастной группы во время «первой волныг» COVID-19. Отношение людей исследуемой украинской группь людей среднего возраста к феномену смерти в условиях пандемии COVID-19 имеет амбивалентный с превалированием негативного характер. Аля людей среднего возраста мыгсли о смерти не является главнылми, мыгли о собственной смерти - амбивалентные, а ровень стрессоустойчивости, который связан с мыслями о смертии, является средним. Аюди боятся, в частности, не самой смерти и прекращении своего существования, а тяжелого и мучительного прочесса умирания. Определено, ито отношение к смерти связано с мвгслями о собственной смерти в исследуемой группе. Оптимистическое отношение к смертии связано с позитивныли мыслями о собственной смерти. Рассмотрены проблемы веры в жизнь после смерти, а также влияния религиозности на страх смерти. Наличие большего количества положительных метафор о смерти, вера в жизнь после смерти, возможность воссоединения с роднылми, мудрость и прощение стало основой значимьгх различий результатов межу группами верующих и атеистов. Атеисть, которых в феномене смерти пугает потеря физического мира, представляюот земную жизнь единственной и считаюот, что те, кто умирают, испьтыгватот страх и безнадежность перед смертью, чаще въбирали негативныге метафоры о собственной смерти. Были определены значимыге различия между размыгилениями о смерти у женщин и мужчин. Женщины, в отличие от мужчин, имеюот более пессимистические размышиления о феномене смерти. Женщины чаще мужчин считают, что думать о смерти возмутительно и указывают, ито мысли о смерти их пугают и травмируют.

Кнючевые слова: психология; отношение; смерть; СОVID-19; религиозность.

НаАійшла до редакції 05.09.2020. 